\title{
Tripropeptins, Novel Antimicrobial Agents Produced by Lysobacter sp.
}

\section{Taxonomy, Isolation and Biological Activities}

\author{
Hideki Hashizume*, Masayuki Igarashi, Seiko Hattori, Makoto Hori, \\ MASA HAMADA and TOMIO TAKEUCHI \\ Institute of Microbial Chemistry, \\ 3-14-23 Kamiosaki, Shinagawa-ku, Tokyo 141-0021, Japan
}

(Received for publication July 2, 2001)

Peptide antibiotics tripropeptins A, B, C, D and Z were isolated from cultured cells and broth of Lysobacter sp. The differences among these components are in the lengths of the alkyl side chain. Tripropeptins are active against Gram-positive bacteria including MRSA in vitro. Bactericidal activity of tripropeptin $C$ disappeared in the simultaneous presence of chloramphenicol, a bacteriostatic agent.

In our screening program for new antibiotics that are active against drug-resistant bacteria, we discovered novel compounds, tripropeptins (Fig. 1), produced by a species of Lysobacter $^{1,2)}$ (BMK333-48F3). These antibiotics were isolated from Lysobacter cultures grown at $27^{\circ} \mathrm{C}$ for 2 days.
We describe here the taxonomy of the producing organism, fermentation conditions, isolation procedures and some characteristics of the antibiotics. Structural studies will be reported in papers to follow.

Fig. 1. Structure of tripropeptins.

Proline<smiles>CC(C)CCCC(NC(=O)C1CCCN1C(=O)C1CCCN1C(=O)C(NC(=O)CC(P)OC(=O)C(NC(=O)C1C(O)CCN1C(=O)C(CO)NC(=O)C(NC(=O)C(NC(=N)N)C(O)C(=O)O)C(O)C(=O)O)C(C)O)C(=O)O)C(=O)O</smiles>

R: $\quad$ tripropeptin

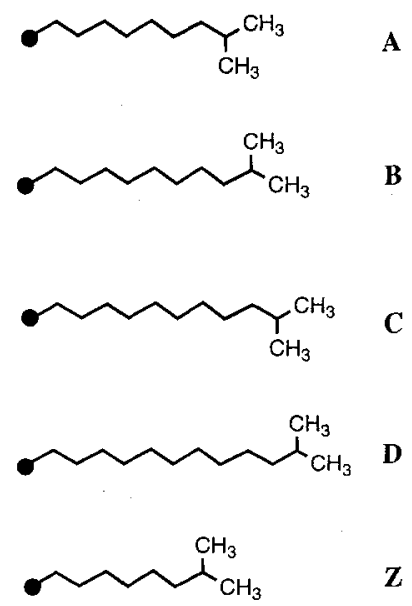

3-OH-Aspartic acid

3-OH-Aspartic acid

Serine 3-OH-Proline

\footnotetext{
* Corresponding author: hashizumeh@bikaken.or.jp
} 


\section{Materials and Methods}

The Antibiotic-producing Organism

The antibiotic-producing organism was isolated from a soil sample collected at Naha, Okinawa prefecture, Japan, and was deposited at the National Institute of Advanced Industrial Science and Technology, under the accession number of FERM BP-7477.

\section{Fermentation}

A seed culture of the tripropeptins-producing organism was prepared by transferring a loopful of surface growth from an agar slant into a 500-ml volume baffled Erlenmeyer flask containing $110 \mathrm{ml}$ of a culture medium consisting of $1.5 \%$ glycerol, $1.5 \%$ cotton seed meal, $0.3 \% \mathrm{NaCl}, 0.5 \%$ sodium L-glutamate monohydrate and deionized water to volume ( $\mathrm{pH} 7.4$ before sterilization). The inoculated medium was incubated on a rotary shaker $(180 \mathrm{rpm})$ at $27^{\circ} \mathrm{C}$ for 1 day (seed culture). A $2 \%$ transfer was made from the seed culture to 450 Erlenmeyer flasks of the same model, each containing $110 \mathrm{ml}$ of the same medium. The inoculated medium (in the 450 flasks) was incubated likewise for 2 days. The contents of the flasks were combined (fermentation broth) and submitted to isolation procedures of the antibiotics.

\section{Antibacterial Activity}

Antibacterial activities of the fractions containing tripropeptins were assayed using a cup or paper-disk diffusion method against Staphylococcus aureus Smith (S. aureus Smith) and Micrococcus luteus IFO3333. Minimum inhibitory concentrations (MICs) of tripropeptins against a wide range of bacteria and yeast were determined using the serial agar dilution method; Mueller Hinton agar (Difco) was used for bacteria except Enterococci for which Mueller Hinton agar (Difco) containing 5\% sheep blood was used.

\section{Bactericidal Activity of Tripropeptin C}

Four tenth $\mathrm{ml}$ of a seed culture of $S$. aureus Smith in a nutrient medium was transferred to L-shaped tubes, each containing $8 \mathrm{ml}$ of the same medium, and incubated at $37^{\circ} \mathrm{C}$ with shaking until an optical density (OD) at $600 \mathrm{~nm}$ (using a COLEMAN spectrometer) reached approximately 0.1 . Tripropeptin C and/or chloramphenicol, at appropriate dilutions, were added to the cultures (referred to as 0 minute). Incubation was continued and at 30,60, 120 and 180 minutes of incubation, OD at $600 \mathrm{~nm}$ were measured and a $100 \mu \mathrm{l}$ sample of each culture was taken and diluted with $9.9 \mathrm{ml}$ of ice cold sterile saline. After serial $1 / 10$ dilutions, $100 \mu \mathrm{l}$ portions were spread on nutrient agar plates, which were incubated at $37^{\circ} \mathrm{C}$ for 18 hours, and numbers of colonies (CFU) were counted.

\section{Results and Discussion}

\section{Taxonomy}

Physiological characteristics of strain BMK333-48F3 are shown in Table 1. The organism is an aerobic, Gramnegative, non-sporulating rod $(0.5 \sim 0.8 \mu \mathrm{m} \times 1.6 \sim 2.0 \mu \mathrm{m})$ bacterium. It has no flagella and exhibits a spreading growth on the agar surface due to gliding motility. Fruit bodies are not produced. $\mathrm{G}+\mathrm{C} \mathrm{mol} \%$ in DNA is $70.5 \%$.

Optimum growth temperature ranges $24 \sim 30^{\circ} \mathrm{C}$. Some acids were generated from glucose, D-fructose, maltose and trehalose, while gas was not generated. Neither acid nor gas was generated from D-xylose, D-mannose, D-galactose, sucrose, arabinose, D-sorbitol, D-mannitol, inositol, glycerol or starch.

From descriptions in the BERGEY's Manual of Systematic Bacteriology ${ }^{2)}$, these characteristics indicate that the organism belongs to the Genus Lysobacter.

\section{Isolation of the Antibiotics}

A fermentation broth (50 liters) was centrifuged and the cells were separated from the supernatant. The cells were extracted with 10 liters of methanol and the extract was concentrated in vacuo leaving an oily residue. The residue was combined with the supernatant and the mixed solution was applied to a Diaion HP20 column (Mitsubishi Chemical Co., 6 liters wet volume). The column was washed with 18 liters of deionized water and 18 liters of $50 \%$ aqueous methanol. Active principles were then eluted with 18 liters of $65 \%$ aqueous acetone. The aqueous acetone eluate was concentrated in vacuo to yield a brown oil (30 $\mathrm{g}$ ), which was chromatographed using a silica gel column (1500 $\mathrm{ml}$ wet volume) developed successively with $4500 \mathrm{ml}$ each of $\mathrm{CHCl}_{3}: \mathrm{MeOH}: \mathrm{H}_{2} \mathrm{O} / 10: 5: 1$ and $\mathrm{BuOH}: \mathrm{MeOH}$ : $\mathrm{H}_{2} \mathrm{O} / 4: 1: 2$. Active fractions, eluted with the latter solvent mixture, were collected and concentrated in vacuo to give a yellowish brown oil $(10.8 \mathrm{~g})$. The oil was dissolved in a small volume of $50 \%$ aqueous methanol, adjusted to $\mathrm{pH}$ 2.6 , and subjected to column chromatography using $250 \mathrm{ml}$ wet volume of CHP20P (Mitsubishi Chemical Co.), eluted with stepwise gradients of acetone $\mathrm{H}_{2} \mathrm{O}(750 \mathrm{ml}$ each of $4: 16,7: 13,8: 12,9: 11,10: 10,11: 9$ and $12: 8 \mathrm{v} / \mathrm{v})$. Active components (their designated numbers printed in boldface) and their dry weights and ratios of acetone : $\mathrm{H}_{2} \mathrm{O}$ 
Table 1. Taxonomic data of strain BMK333-48F3.

\begin{tabular}{lc|cc}
\hline Characterization & & Characterization & \\
\hline Gram stain & - & Decomposition of glucose & + \\
Motility & - & D-mannose & - \\
Gliding & + & maltose & + \\
Fruit bodies & - & sucrose & - \\
G+C contents & $70.5 \%$ & D-galactose & - \\
Peptonization of milk & + & D-fructose & + \\
Coagulation of milk & + & arabinose & - \\
Chitin degradation & + & inositol & - \\
Catalase & + & D-mannitol & - \\
Oxidase & + & trehalose & + \\
Urease & - & D-sorbitol & - \\
Indole test & - & D-xylose & - \\
$\mathrm{H}_{2}$ S test & - & cellobiose & - \\
Nitrate reduction & + & glycerol & - \\
Denitrification & - & starch & - \\
Methyl red test & - & salicin & - \\
Voges-Proskauer test & - & lactose & - \\
Citrate utilization & + & Acid fast & \\
Hydrolysis of Casein & + & phigments & \\
Gelatin liquefaction & + & Temperature range for growth & $20-37^{\circ} \mathrm{C}$ \\
O/F test & + & Optimum growth temperature & $24-30^{\circ} \mathrm{C}$ \\
\hline
\end{tabular}

(in parentheses) are as follows; $5(65.7 \mathrm{mg}, 8: 12), 1(189.7$ $\mathrm{mg}, 9: 11), 2$ (210.6 mg, 9:11 and 10:10), 3 (986.6 mg, $9: 11$ and $10: 10)$ and $4(50.1 \mathrm{mg}, 10: 10,11: 9$ and $12: 8)$. Tripropeptins were successfully separated into these components using the CHP20P column chromatography as described above but thin-layer chromatographical methods with different solvent systems tested so far failed to separate them. Tripropeptins are soluble in methanol, water and dimethyl sulfoxide, while insoluble in acetone, ethyl acetate and chloroform.

\section{Biological Activities}

As shown in Table 2, tripropeptin $\mathrm{C}$ strongly inhibited growth of Gram-positive bacteria including MRSA, but was not active against Gram-negative bacteria, Mycobacterium and Candida.

Table 3 shows antimicrobial activities of tripropeptin A, $B, C, D$ and $Z$ and, for comparison, arbekacin, against Gram-positive and a few Gram-negative bacteria. Among tripropeptins, antimicrobial activities paralleled the lengths of side chains, the longer the more active. Vancomycinresistant enterococci were as sensitive to tripropeptins as were the vancomycin-sensitive counterparts.

Tripropeptin $\mathrm{C}$ acted as a bactericidal agent against
$S$. aureus Smith and the bactericidal activity was abolished by the simultaneous presence of chloramphenicol, as shown in Fig. 2. Tripropeptin $\mathrm{C}$ at $2.5 \mu \mathrm{g} / \mathrm{ml}$ was a marginal concentration to inhibit the increase in the turbidity of $S$. aureus Smith in a shaken culture (Fig. 2-a; results at other concentrations are not shown). Although the turbidity of the culture remained almost the same for 3 hours after the addition of tripropeptin C, numbers of viable cells (CFU) in the suspension dropped rapidly with incubation time (Fig. 2-b). Interestingly, the simultaneous presence of $2.5 \mu \mathrm{g} / \mathrm{ml}$ of chloramphenicol, a bacteriostatic agent, abolished the bactericidal activity of tripropeptin C (Fig. 2-b).

Tripropeptin $\mathrm{C}$ did not show an acute toxicity in mice at a dose of $300 \mathrm{mg} / \mathrm{kg}$ when administered intravenously.

\section{Discussion}

Tripropeptins are compared with known antibiotics of bacterial origin in view of structure and activity, as follows. Empedopeptin ${ }^{3,4)}$ produced by Empedobacter sp., another inhibitor of Gram-positive bacteria, has the same amino acid residues as those of tripropeptins, but the amino acid sequence of empedopeptin is different from that of tripropeptins. Furthermore, a tripropeptin has a branched 
Table 2. Antimicrobial activities of tripropeptin C.

\begin{tabular}{|c|c|}
\hline Test organisms & $\operatorname{MIC}(\mu \mathrm{g} / \mathrm{ml})$ \\
\hline Staphylococcus aureus FDA209P & 0.78 \\
\hline S. aureus Smith & 0.78 \\
\hline S. aureus MS9610 & 0.78 \\
\hline S. aureus No.5(MRSA) & 0.78 \\
\hline S. aureus No.17(MRSA) & 3.12 \\
\hline S. aureus MS16526(MRSA) & 0.78 \\
\hline S. aureus TY-04282(MRSA) & 1.56 \\
\hline Micrococcus luteus IFO3333 & $<0.2$ \\
\hline M.luteus PCI1001 & $<0.2$ \\
\hline Bacillus subtilis NRRL B-558 & 0.39 \\
\hline B. cereus ATCC 10702 & 6.25 \\
\hline Corynebacterium bovis 1810 & 0.39 \\
\hline Escherichia coli $\mathrm{NIHJ}$ & $>100$ \\
\hline Shigella dysenteriae JS 1910 & $>100$ \\
\hline Salmonella enteritidis & $>100$ \\
\hline Proteus mirabilis IFM OM-9 & $>100$ \\
\hline Serratia marcescens & $>100$ \\
\hline Pseudomonas aeruginosa A3 & $>100$ \\
\hline Klebsiella pneumonie PCI602 & $>100$ \\
\hline Mycobacterium smegmatis ATCC $607^{\text {a }}$ & 100 \\
\hline Candida albicans 3147 & $>100$ \\
\hline Enterococcus faecalis JCM $5803^{\mathrm{b}}$ & 12.5 \\
\hline Enterococcus faecium JCM $5804^{\mathrm{b}}$ & 12.5 \\
\hline E. faecalis NCTC 12201 (VCM R) ${ }_{b}^{b}$ & 6.25 \\
\hline E. faecium NCTC 12202 (VCM R) & 12.5 \\
\hline E. faecalis NCTC12203 (VCM R) ${ }^{\mathrm{b}}$ & 25 \\
\hline E. faecium NCTC 12204 (VCM R) & 12.5 \\
\hline
\end{tabular}

Mueller Hinton agar (Difco), $37^{\circ} \mathrm{C} 18$ hours, except a and b. a: $37^{\circ} \mathrm{C} 42$ hours.

b: Mueller Hinton agar(Difco) $+5 \%$ Sheep blood, $37^{\circ} \mathrm{C} 18$ hours

Table 3. Antimicrobial activities of tripropeptins.

\begin{tabular}{|c|c|c|c|c|c|c|c|c|}
\hline \multirow{2}{*}{ test organism $\backslash \mathrm{MIC}(\mu \mathrm{g} / \mathrm{ml})$} & \multicolumn{5}{|c|}{ tripropeptin } & \multirow{2}{*}{ arbekacin } & \multirow{2}{*}{ vancomycin } & \multirow{2}{*}{ gentamicin } \\
\hline & $\mathbf{A}$ & B & $\mathrm{C}$ & D & $\mathbf{Z}$ & & & \\
\hline Staphylococcus aureus FDA 209P & 1.56 & 1.56 & 1.56 & 0.39 & 12.5 & 0.10 & 0.39 & $<0.2$ \\
\hline S. aureus Smith & 0.78 & 1.56 & 1.56 & 0.39 & 6.25 & 0.10 & 0.39 & $<0.2$ \\
\hline S. aureus MS9610 & 6.25 & 3.13 & 1.56 & 0.78 & 25 & 1.56 & 0.39 & $<0.2$ \\
\hline S. aureus MS16460(MRSA) & 6.25 & 6.25 & 3.13 & 1.56 & 50 & 6.25 & N.D. & $>800$ \\
\hline S. aureus MS16497(MRSA) & 6.25 & 3.13 & 1.56 & 0.78 & 25 & 0.39 & N.D. & 0.78 \\
\hline S. aureus MS16526(MRSA) & 3.13 & 3.13 & 1.56 & 0.78 & 25 & 25 & 0.78 & $>800$ \\
\hline S. aureus TY-00933(MRSA) & 6.25 & 3.13 & 3.13 & 0.78 & 25 & 3.13 & 0.78 & $>100$ \\
\hline S. aureus TY-03454(MRSA) & 6.25 & 3.13 & 1.56 & 0.78 & 25 & 0.39 & 0.39 & 100 \\
\hline S. aureus TY-03456(MRSA) & 6.25 & 3.13 & 3.13 & 0.78 & 25 & 1.56 & 0.78 & $>100$ \\
\hline S. aureus TY-04282(MRSA) & 6.25 & 3.13 & 1.56 & 0.78 & 25 & 0.39 & 0.39 & 0.06 \\
\hline Enterococcus faecalis JCM5803*. & 50 & 25 & 12.5 & 3.13 & 100 & 12.5 & 0.78 & N.D. \\
\hline Enterococcus faecium JCM5804* & 50 & 25 & 12.5 & 6.25 & $>100$ & 12.5 & 0.78 & N.D. \\
\hline E. faecalis NCTC 12201 VCM R* & 50 & 12.5 & 6.25 & 3.13 & 100 & 100 & $>400$ & N.D. \\
\hline E. faecium NCTC 12202 VCM R* & 50 & 25 & 12.5 & 6.25 & $>100$ & 50 & $>400$ & N.D. \\
\hline E. faecalis NCTC 12203 VCM R* & 50 & 50 & 25 & 6.25 & $>100$ & 50 & 400 & N.D. \\
\hline E. faecium NCTC 12204 VCM R*. & 50 & 25 & 12.5 & 6.25 & $>100$ & 25 & 400 & N.D. \\
\hline
\end{tabular}


Fig. 2-a. Effect of tripropeptin C (TPPC) and/or chloramphenicol (CP) on cell growth.

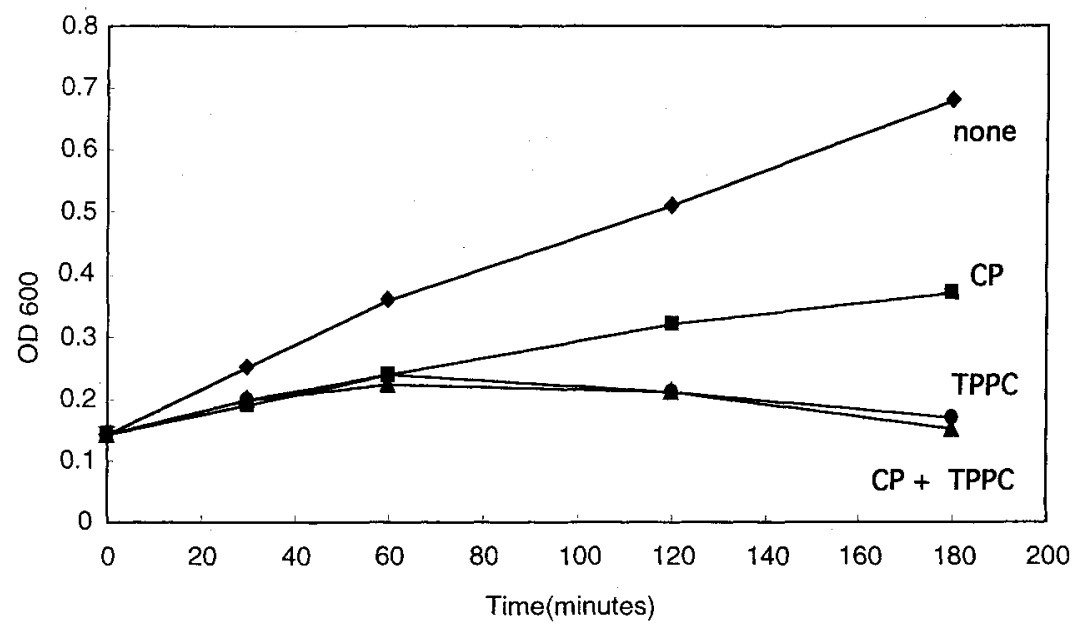

Fig. 2-b. Effect of tripropeptin C (TPPC) and/or chloramphenicol (CP) on numbers of viable cells.

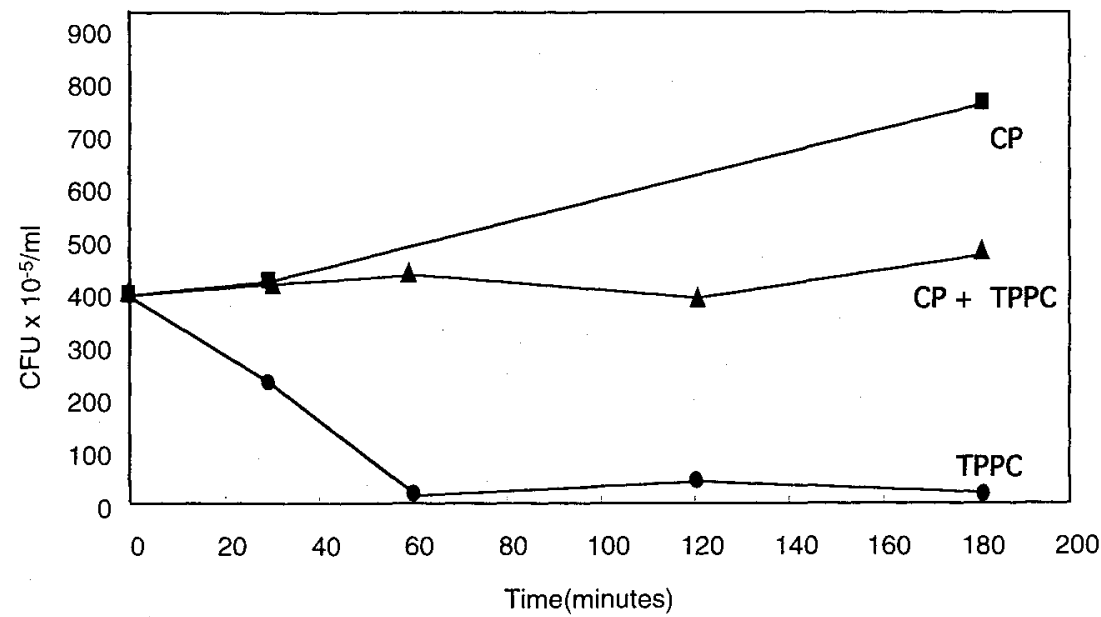

Chloramphenicol was added 10 minutes prior to tripropeptin $\mathrm{C}$ addition.

Concentrations of both agents are $2.5 \mu \mathrm{g} / \mathrm{ml}$.

Abbreviations: CP, chloramphenicol; TPPC, tripropeptin C

alkyl chain while empedopeptin has a linear alkyl chain. Plusbacins ${ }^{5,6)}$ produced by Pseudomonas sp., seem to be the closest in their structures to tripropeptins, differing only in the amino acid composition, and also active against Grampositive bacteria.

The antagonism between tripropepin $\mathrm{C}$ and chloramphenicol in respect to cell killing may be explained as follows. It is possible that tripropeptin $\mathrm{C}$ inhibits synthesis of the cell envelope but allows the increase in the intracellular contents, leading the cells to burst. Reversible inhibition by chloramphenicol of protein synthesis seems to protect cells from bursting. MAKI H. et al. recently reported that plusbacin $\mathrm{A}_{3}$ inhibited peptidoglycan synthesis?).

Acknowledgement

We are grateful to MERCIAN CORPORATION for preparation of the crude antibiotics. 


\section{References}

1) Christensen, P. \& F. D. Cook: Lysobacter, a new genus of nonfruiting, gliding bacteria with a high base ratio. Int. J. Syst. Bacteriol. 28: 367 393, 1978

2) Christensen, P.: Genus I. Lysobacter Christensen and Cook 1978, 372. Bergey's Manu. Syst. Bacteriol. 3. Edited by Staley, J. T.; M. P. Bryant, N. Pfenning \& J. G. HOLT: pp. 2083 2089, 1989

3) Konishi, M.; K. Sugawara, M. Hanada, K. Tomita, K. Tomatsu, T. Mryake, H. Kawaguchi, R. E. Buck, C. MORE \& V. Z. Rossomano: Empedopeptin (BMY28117), a new depsipeptide antibiotic. I. Production, isolation and properties. J. Antibiotics 37: 949 957, 1984

4) Sugawara, K.; K. Numata, M. Konishi \& H.
KaWAGUCHI: Empedopeptin (BMY-28117), a new depsipeptide antibiotics. II. Structure determination. J. Antibiotics 37: 958 964, 1984

5) Shojl, J.; H. Hinoo, T. Katayama, K. Matsumoto, T. Tanimoto, T. Hattori, I. Higashiyama, H. Miwa, K. MOTOKAWA \& T. YOSHIDA: Isolation and characterization of new peptide antibiotics, plusbacins $A_{1} \sim A_{4}$ and $\mathrm{B}_{1} \sim \mathrm{B}_{4}$. J. Antibiotics 45: 817 823, 1992

6) Shoji, J.; H. Hinoo, T. Katayama, Y. Nakagawa, Y. IKENISHI, K. IWATANI \& T. YOSHIDA: Structures of new peptide antibiotics, plusbacins $A_{1} \sim A_{4}$ and $B_{1} \sim B_{4} . J$. Antibiotics 45: 824 831, 1992

7) MaKi, H.; K. Miura \& Y. Yamano: Katanosin B and plusbacin $A_{3}$, inhibitors of peptidoglycan synthesis in methicillin-resistant Staphylococcus aureus. J. Antimicrob. Chemother. 45: 1823 1827, 2001 